\title{
AKURASI DALAM APLIKASI TEKNOLOGI STIMULASI HORMON UNTUK PEMIJAHAN IKAN
}

\author{
Darti Satyani* \\ *) Loka Riset Budidaya Ikan Hias Air Tawar, Depok
}

\begin{abstract}
ABSTRAK
Teknologi stimulasi untuk pemijahan ikan menggunakan hormon, khususnya hormon gonadotropin untuk merangsang induk-induk ikan agar dapat ovulasi dan spermiasi. Teknologi ini banyak digunakan orang, terutama pada ikan-ikan yang sulit dipijahkan secara alami. Keberhasilan dalam penggunaan teknologi tersebut cukup baik, namun kegagalan juga masih banyak ditemui oleh para pembudidaya. Hal ini lebih sering disebabkan karena ketidaktepatan atau kurang akurasi dalam setiap proses atau tahapan dalam penerapannya. Mulai dari pemilihan induk, penentuan kadar hormon, cara penyuntikan, pengeluaran telur sampai ke pemijahan atau pembuahan telurnya memang memerlukan kecermatan dalam aplikasinya. Kriteria atau standar yang benar dari setiap proses harus dipatuhi agar teknologi stimulasi dapat memberikan hasil yang maksimal seperti induk harus benar-benar matang gonad, kadar hormon harus tepat, serta cara pemijahan atau pembuahan harus disesuaikan dengan jenis ikannya.
\end{abstract}

KATA KUNCl: akurasi, teknologi, pemijahan

\section{PENDAHULUAN}

Penerapan teknologi stimulasi untuk pemijahan ikan dengan cara suntik hormon baik itu pada ikan konsumsi maupun ikan hias sudah banyak dilakukan orang. Ikanikan yang baru didomestikasikan maupun ikan-ikan lain yang sulit untuk memijah secara alami teknologi ini sangat membantu dan bermanfaat. Keberhasilan dari teknologi ini cukup baik tetapi dalam prakteknya sering hasilnya tidak maksimal dan kadang masih sering ditemui banyak kegagalan.

Proses pemijahan dimulai dari pemilihan induk, cara penyuntikan/stimulasi, pengeluaran telur dan sperma sampai pada pemijahan atau pembuahan memerlukan ketelitian yang tinggi agar hasilnya dapat maksimal. Apabila salah satu dari urutan proses di atas tidak dilakukan dengan baik maka akan mengalami kegagalan.
Kerugian akan makin besar apabila kesalahan terjadi pada proses yang sudah berlangsung lebih jauh/lanjut. Artinya, andaikan kesalahan terjadi masih dalam pemilihan induk maka kegagalan mungkin akan terjadi dalam pengeluaran telur, sehingga kerugian hanya pada hormon yang disuntikkan saja. Apabila terjadi kesalahan sudah dalam tahap pengeluaran telur maka kegagalan akan terjadi dalam pembuahan dan akan mengalami kerugian yang lebih besar. Kerugian dalam hal waktu, tenaga, dan biaya akan lebih besar, karena tentu untuk persiapan tahap lanjutan sudah disediakan seperti tempat inkubasi telur maupun pemeliharaan larva. Belum lagi akan kehilangan telur dan sperma yang mungkin bagus kualitasnya. Oleh karena itu, ketelitian pelaksanaan dalam menangani setiap tahapan proses sangat diperlukan.

\section{SELEKSI/PEMILIHAN INDUK MATANG GONAD}

Induk ikan yang akan diperlakukan dengan suntikkan hormon harus benar-benar sudah siap atau matang gonad. Secara visual induk matang gonad pada yang betina adalah yang perutnya gendut karena mengandung telur. Agar tidak rancu dengan ikan yang amat kenyang (yang juga kadang gendut), maka seleksi akan baik dilakukan pada ikan yang dipuasakan terlebih dahulu selama 24 jam.

Dengan melakukan perabaan pada perut maka induk ikan betina yang telah matang gonad adalah yang terasa

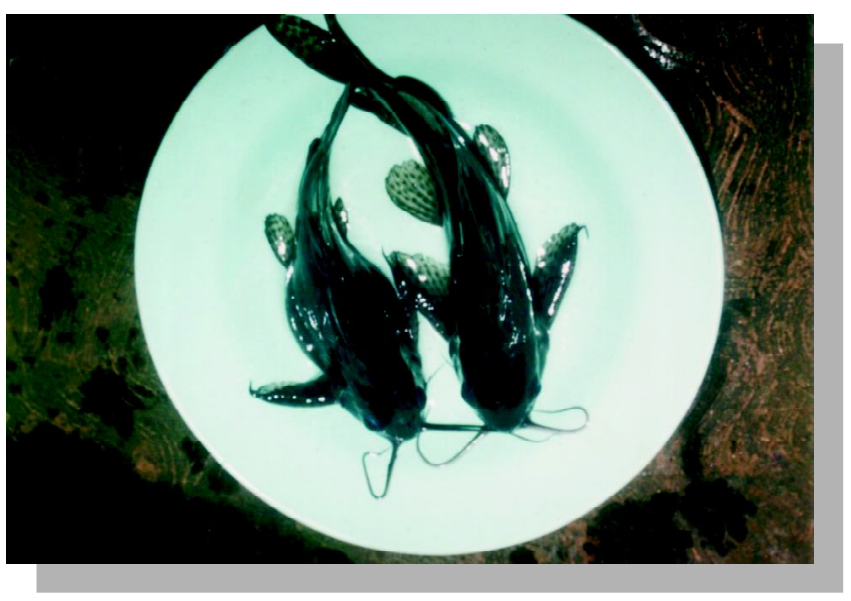

Gambar 1. Induk ikan Synodontis sp. matang gonad, betina dengan perut gendut (kiri) dan jantan yang langsing (kanan) 
lembek dan gendutnya sudah agak turun kebawah kearah lubang genital atau lubang kelamin. Beberapa ikan ditandai pula dengan lubang kelamin yang berwarna lebih cerah (merah) dan melebar serta membengkak.

Untuk akurasi atau lebih telitinya maka cara kanulasi atau kateterisasi akan lebih tepat karena dapat menentukan kondisi telur ikan dengan benar. Kanulasi adalah cara mengambil contoh telur dari dalam tubuh ikan, dengan cara memasukkan selang kateter melalui lubang genital. Ukuran kateter dapat disesuaikan dengan ukuran lubang kelamin dan telur dari ikannya. Contoh telur ini akan menentukan kematangan gonad. Biasanya apabila telur ukurannya sudah maksimal menandakan sudah matang gonad, umumnya berkisar antara 1,0--4,0 mm. Ukuran ini tergantung dari jenis ikannya. Ikan botia misalnya ukuran sekitar 1,0--1,2 mm sudah matang gonad, tiger catfish 1,3--1,4 mm sementara ikan trout matang gonadnya mencapai 4,0 mm (Billard, 1982; Satyani et al., 1999). Kriteria lain yang dapat dilihat adalah dari warna telur. Warna telur tergantung dari jenis ikannya, tetapi telur yang matang warnanya akan lebih tua dari yang muda. Selain itu telur yang sudah matang tampak lebih jernih. Telur yang matang terpisah satu sama lain yang artinya sudah tidak lagi dalam untaian (gumpalan).

Bagi induk jantan lebih mudah menentukannya karena dengan pengurutan perut biasanya sperma sebagai tanda matang gonad akan keluar dari lubang genital. Sperma yang keluar dari lubang genital berupa cairan kental umumnya berwarna putih seperti susu.

\section{PENYUNTIKAN HORMON}

\section{Jenis dan Kadar Hormon yang Digunakan}

Hormon gonadotropin untuk stimulasi pemijahan yaitu hormon untuk merangsang keluarnya telur dan sperma ikan. Hormon tersebut banyak dijual dalam berbagai merek. Misalkan produk "ovaprim" yang amat dikenal dan luas digunakan berisi gonadotropin dan dopamin. HCG (Human Chorionic Gonadotropin) berisi gonadotropin dari plasenta mamalia.

Umumnya hormon ini dijual dalam kemasan tertentu dan sudah memiliki aturan penggunaannya, tetapi karena kepekaan dari setiap ikan berlainan maka kadar yang tepat harus dicari. Kadar hormon biasa dihitung dengan satuan per bobot ikannya. Agar keberhasilan dari tujuan tercapai yaitu merangsang keluarnya telur dan sperma maka kadar ini harus tepat. Kadar yang kurang tidak akan direspon oleh tubuh ikan sementara kadar yang berlebih selain boros juga dapat membahayakan kesehatan ikan. Efek samping dari hormon yang berlebih ini menurut
Donaldson \& Hunter (1983), adalah arteriosclerosis atau penyempitan pembuluh darah yang dapat menyebabkan kematian ikan.

Untuk menentukan jumlah hormon yang akan disuntikkan maka bobot ikan tentu harus ditimbang terlebih dulu. Penggunaan timbangan disesuaikan dengan besar ikan. Untuk ikan yang berukuran kecil (10--70 gram) seperti platydoras, redfin, Botia lokahata timbangan yang digunakan juga harus yang kecil, dengan ketelitian 0,1 gram. Sementara ikan berukuran sedang seperti Synodontis, ikan daun (Ctenopoma sp.) dengan bobot antara 40--150 gram dapat digunakan timbangan yang lebih besar. Kemudian untuk aligator, patin yang bobotnya lebih dari 1 (satu) kg timbangannya juga harus lebih besar lagi.

Ketelitian dalam memasukkan hormon terutama pada ikan berukuran kecil dapat dilakukan dengan penggunaan spuit/syringe yang kecil. Ukuran 0,5 atau 1,0 mL dengan garis skala 10 garis setiap $0,1 \mathrm{~mL}$ merupakan pilihan yang tepat. Dengan demikian jumlah hormon yang hanya 0,01 $\mathrm{mL}$ dapat terhitung atau terukur dengan baik. Pada tabung suntik atau spuit $0,5 \mathrm{~mL}$ jarum suntiknya paten tidak dapat dilepas. Jarum cukup halus/kecil sehingga cocok untuk ikan kecil karena bekas jarum hampir tidak kelihatan di badan ikan. Untuk ikan yang besar jarum suntik dapat disesuaikan dengan ikannya. Jarum yang kecil untuk ikan berukuran besar sering kurang efektif karena tidak masuk kedalam jaringan sehingga hormon dapat keluar lagi pada saat jarum ditarik. Oleh karena itu, saat penyuntikan harus perlahan-lahan dan bila hormon sudah ditekan masuk ke tubuh ikan tunggu beberapa saat agar hormon benar-benar masuk, baru ditarik jarumnya.

\section{Waktu dan Cara Penyuntikan}

Waktu penyuntikan ikan umumnya sore hari atau malam hari mulai pukul 15.00--21.00. Pada beberapa ikan penyuntikan induk betina dilakukan dua kali tetapi ada pula yang satu kali. Apabila dikerjakan dua kali maka suntikan pertama adalah sepertiga, sisanya dimasukkan pada suntikan kedua, dengan interval waktu sekitar 6 (enam) jam. Untuk ikan jantan penyuntikan hanya satu kali saja dengan kadar 2/3 (dua pertiga) atau dapat juga sama dengan kadar betinanya. Waktunya sama dengan saat suntik pertama betina.

Cara penyuntikan atau memasukkan hormon merupakan proses yang sangat penting. Walaupun ikan sudah diperlakukan dengan suntikan tetapi sering terjadi ikan tidak mau ovulasi/spermiasi yang kemungkinan adalah salah dalam cara penyuntikan. Hormon mungkin tidak masuk ke dalam jaringan atau masuk hanya sebagian saja. Oleh karenanya harus dilakukan dengan hati-hati. 
Tempat penyuntikan yang umum adalah di bawah sirip punggung sekitar 0,5--1,0 cm dengan kemiringan $30^{\circ}-45^{\circ}$ kearah kepala (Gambar 2). Pada ikan yang bersisik sisipkan jarum di bawah sisiknya. Untuk ikan yang bersisik keras dapat dilakukan didekat perut (intra peritoneal). Kedalaman jarum suntik ke daging ikan tergantung dari besar kecil ikannya. Ikan-ikan kecil mungkin hanya $1 \mathrm{~cm}$ tetapi untuk ikan besar dapat 4--5 cm.

Pada ikan-ikan yang aktif bergerak dan ikan besar pembiusan dengan phenoxy aetanol 0,3--0,4 mL/L air sebelum dilakukan penyuntikan amat dianjurkan. Hal ini dikerjakan untuk mengurangi rasa sakit dan menghindari ikan meloncat saat jarum masuk kedalam tubuh ikan.

\section{WAKTU LATEN DAN PENGELUARAN TELUR/ SPERMA}

Waktu laten merupakan periode antara waktu suntik dan saat pengeluaran telur. Waktu ini tergantung 2 (dua) faktor yaitu jenis ikan dan suhu media atau air. Pada beberapa ikan waktu ini cukup lama dapat mencapai 20 jam atau lebih (Tiger catfish, aligator, Botia macracanthus)

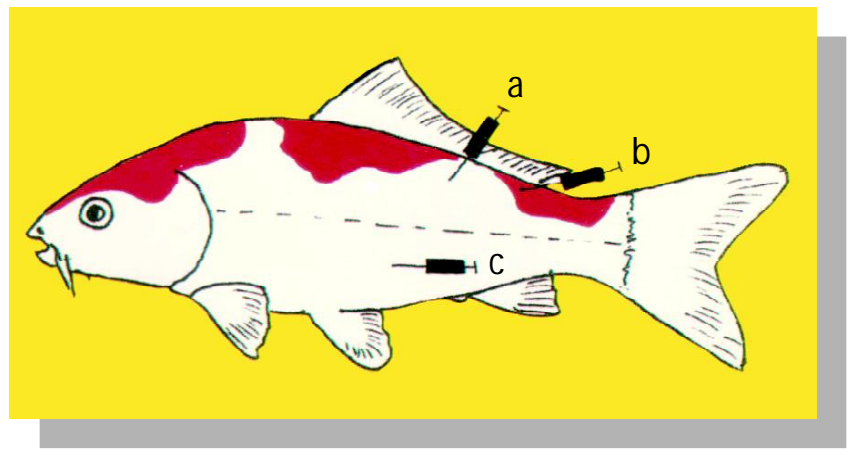

tetapi pada ikan lain hanya singkat saja sekitar 8--10 jam (red fin, Botia lokahata) (Tabel 1) Dengan diketahuinya waktu laten ini maka rencana kerja yaitu waktu suntik dapat diatur disesuaikan dengan kapan ikan diharapkan untuk memijah.

Pengeluaran telur dan sperma ada 2 (dua) macam yaitu pertama dengan cara alami artinya ikan mengeluarkan telur atau sperma dengan sendirinya, sehingga pemijahan dilakukan dengan jalan dipasangkan antara ikan jantan dan betina. Pasangan dilakukan setelah penyuntikan dapat dibuat satu jantan dengan satu betina, atau dua jantan satu betina tergantung dari jenis ikannya. Biasanya setelah selesai ikan mengeluarkan telur atau sperma induk jantan dan betina akan dapat langsung dipindahkan/diambil dan telur dapat ditetaskan dalam akuarium tersebut. Dapat juga dilakukan pemindahan telurnya tetapi untuk ikan seperti aligator yang telurnya melekat hal tersebut akan sulit dilakukan.

Cara kedua adalah dengan pengurutan atau stripping. Harus dilakukan hati-hati dan teliti. Dipastikan memang

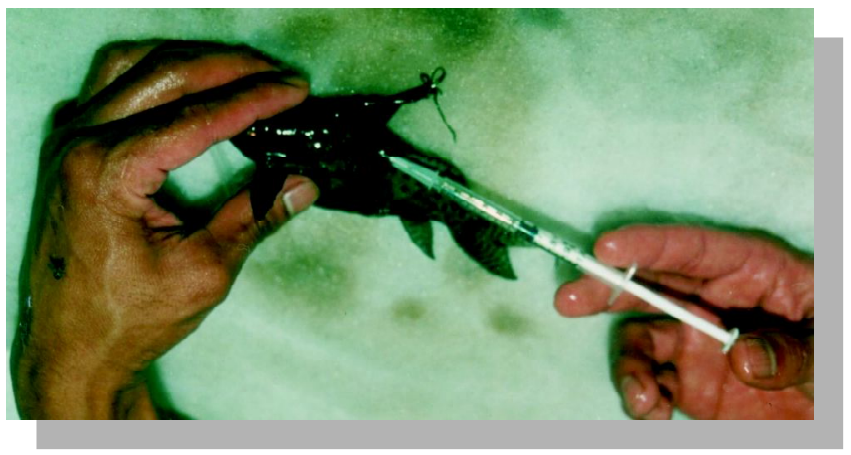

Gambar 2. Tempat suntikan hormon pada ikan

Tabel 1. Ukuran induk, kadar hormon (ovaprim), jumlah suntikan, waktu laten, dan cara pengeluaran telur/ sperma (pemijahan) beberapa jenis ikan

\begin{tabular}{|c|c|c|c|c|c|}
\hline Jenis ikan & $\begin{array}{l}\text { Ukuran induk } \\
\text { (gram) }\end{array}$ & $\begin{array}{c}\text { Kadar hormon } \\
\text { betina/jantan } \\
(\mathrm{mL} / \mathrm{kg})\end{array}$ & $\begin{array}{l}\text { Jumlah } \\
\text { suntikan }\end{array}$ & $\begin{array}{c}\text { Waktu laten } \\
\left(26^{\circ} \mathrm{C}--30^{\circ} \mathrm{C}\right) \\
(\text { jam })\end{array}$ & $\begin{array}{r}\text { Telur/ } \\
\text { sperma } \\
\text { keluar }\end{array}$ \\
\hline Pangasius sp. (Patin) & $1.000-4.000$ & $0,5 / 0,3$ & $2 x$ & $20--22$ & Stripping \\
\hline Platysoma sp. (Tiger catfish) & $1.000-4.000$ & $0,5 / 0,3$ & $2 x$ & $20-22$ & Stripping \\
\hline Botia macracanthus (Botia) & $60--300$ & $1,0 / 0,6$ & $2 x$ & $11--20$ & Stripping \\
\hline Botia lokahata (Botia India) & $10-50$ & $0,5 / 0,5$ & $1 x$ & $6-10$ & Alami \\
\hline Synodontis niger (Sinodontis) & 30--100 & $0,8 / 0,8$ & $1 x$ & $20--22$ & Stripping \\
\hline Platydoras sp. (Platydoras) & $10-60$ & $0,8 / 0,8$ & $1 x$ & $15--20$ & Stripping \\
\hline Ctenopoma sp. (Ikan daun) & 20--100 & $0,5 / 0,5$ & $1 x$ & $10--15$ & Stripping \\
\hline Ballanteocheilus melanopterus (Balashark) & $1.000-3.500$ & $1,0 / 0,6$ & $2 x$ & $15--22$ & Stripping \\
\hline Clarias garipienus (Lele dumbo) & $800-2.000$ & $0,3 / 0,3$ & $1 x$ & $10-15$ & Alami \\
\hline Ephalzeorhynchus sp. (Redfin) & $10-80$ & $0,8 / 0,8$ & $1 x$ & $6-10$ & Alami \\
\hline Lepisosteus oculatus (Aligator) & $800-2.000$ & $1,0 / 1,0$ & $2 x$ & $22--30$ & Alami \\
\hline
\end{tabular}



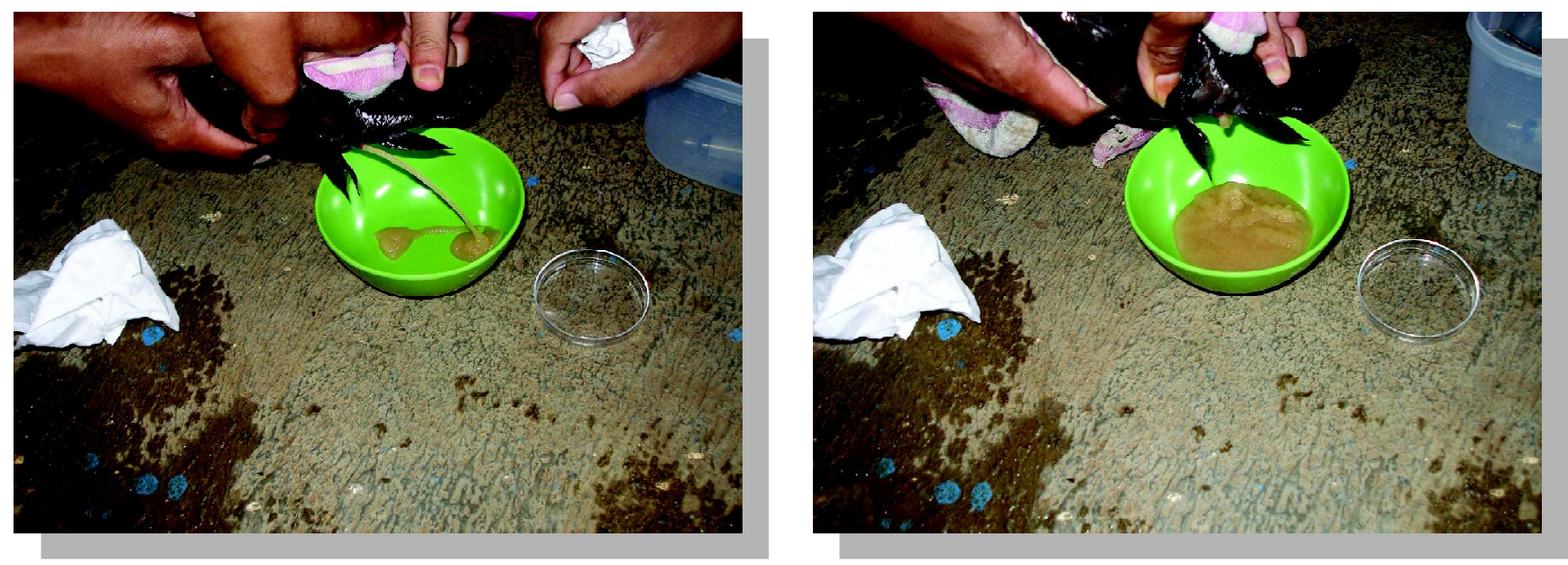

Gambar 3. Stripping Synodontis sp.

sudah waktunya telur keluar. Tanda-tanda ikan yang akan mengeluarkan telur adalah tampak gelisah, ekor dikibaskibaskan dan beberapa ikan sering berenang kesana kemari. Ikan yang sudah waktunya bertelur apabila dilakukan pengurutan dengan urutan lembut di perut sedikit saja telur sudah keluar. Apabila ditekan kuat telur belum keluar juga (masih berat) maka harus ditunggu sampai saatnya tiba. Wadah penampung telur harus kering demikian pula saat stripping ikan sebaiknya dilap dulu sampai kering. Sering terjadi pada akhir pengeluaran, telur keluar bercampur darah. Sebaiknya bila terjadi demikian pengurutan dihentikan. Telur yang bercampur darah pembuahannya sering tidak berhasil.

Telur ovulasi. Telur yang dikeluarkan oleh ikan bentuknya tidak teratur, setelah masuk kedalam air akan menjadi bulat dan mengembang dalam waktu yang cepat. Air akan masuk kedalamnya di antara chorion (kulit telur) dan isi telur membentuk ruang yang disebut ruang perivitellina. Mycropile di mana sperma akan lewat masuk kedalam untuk membuahi inti telur akan tertutup dalam waktu singkat. Lamanya penutupan tergantung dari jenis ikannya, antara satu sampai beberapa menit. Penutupan ini akan mengisolasi telur dalam lingkungan khusus yang terpisah dari lingkungan luar untuk perkembangan embrio supaya aman (Billard, 1989). Oleh karena itu, dalam perlakuan stripping sebelum pencampuran dengan sperma harus diusahakan dalam keadaan betul-betul kering agar telur jangan sampai terkena air dulu sebelum terbuahi.

Sperma. Sperma ikan terdiri atas spermatozoa dan cairan sperma. Apabila masih dalam cairan sperma dan dalam tubuh ikan, maka spermatozoa tidak bergerak atau diam. Apabila spermatozoa masuk kedalam air akan bergerak kearah telur untuk membuahinya. Pergerakan atau motilitas spermatozoa dalam air juga sangat singkat.
Pada ikan air tawar hanya sekitar 40--60 detik, kemudian akan mati. Dengan demikian waktu yang dibutuhkan untuk membuahi telur sangat pendek.

Motilitas spermatozoa juga akan berkurang apabila bercampur dengan urine. Oleh karena itu, dalam stripping sperma harus berhati-hati. Biasanya saat pengurutan pertama kali yang keluar adalah urine berupa cairan bening. Keringkan dulu dengan lap atau tisu cairan ini sampai kering, setelah itu apabila keluar cairan putih seperti susu yaitu sperma dapat dikoleksi/dikumpulkan.

Tempat penampung sperma dapat berupa tabungtabung kecil yang dijaga agar tetap kering selama pengumpulan. Hal ini disebabkan sperma ikan pada kondisi dalam air atau basah akan aktif sehingga akan cepat mati (Billard \& Cosson, 1990). Teknik penyimpanan sperma di dalam garam fisiologis atau larutan garam $\mathrm{NaCl} 0,9 \%$ sangat bagus, karena sperma dalam larutan ini tidak akan bergerak dan tahan sekitar $4--24$ jam dalam suhu $4^{\circ} \mathrm{C}-$ $15^{\circ} \mathrm{C}$.

\section{PEMBUAHAN/FERTILISASI}

Pembuahan atau fertilisasi secara awam adalah bercampurnya telur dan sperma. Secara biologis merupakan proses masuknya spermatozoa kedalam sel telur dan terjadinya fusi antara inti sel telur dan inti spermatozoa. Akhir dari proses pembuahan ini adalah terjadinya zygoteyang akan berkembang menjadi embrio (calon anak).

Pada ikan pembuahan dapat terjadi secara alami yaitu induk ikan betina akan mengeluarkan telurnya sendiri dan segera diikuti oleh jantan yang mengeluarkan sperma didekatnya. Pembuahan akan terjadi di dalam air. Dengan demikian induk-induk harus ditempatkan berpasangan. Pembuahan alami pada ikan yang disuntik hormon ini 
umumnya terjadi pada ikan-ikan seperti lele dumbo (Clarias gariepienus), redfin (Ephalzeorhynchus sp.), Botia lokahata, dan spotted gar (Aligator).

Pembuahan buatan yaitu dengan cara mencampurkan telur dan sperma yang dikeluarkan dari induk dengan cara stripping dikerjakan pada ikan-ikan yang lain. Karena dikerjakan dengan bantuan tangan manusia maka harus dikerjakan sesuai dengan sifat ikannya, walaupun sebenarnya hampir sama pada semua ikan.

Telur yang sudah dikoleksi dimasukkan ke wadah yang licin dituangi sperma dari koleksi secukupnya, kemudian perlahan-lahan ditambahkan air bersih. Apabila jumlah telur banyak seperti ikan patin (Pangasius sp.) atau tiger catfish (Platysoma sp.) pencampuran dapat dilakukan dengan mengaduknya menggunakan bulu ayam atau kuas halus agar merata. Untuk ikan yang telurnya sedikit cukup wadahnya digoyang-goyangkan. Pencampuran harus cepat terutama sesudah ditambah air, mengingat umur spermatozoa yang pendek dan tertutupnya micropyle telur dalam waktu singkat sesudah terkena air. Telur yang sudah terbuahi ini dapat dicuci dengan air bersih beberapa kali agar sisa-sisa sperma hilang. Sesudah itu dapat ditebar/ ditetaskan di tempat penetasan (akuarium, bak, atau corong).

Telur ikan yang bersifat melekat dapat diperlakukan dengan larutan carbamida atau larutan urea dan garam. Carbamida (urea) 4 gram yang dicampur garam $(\mathrm{NaCl})$ sebanyak 3 gram yang dilarutkan dalam 1 (satu) liter air (Woynarovich \& Hovarth, 1987) digunakan untuk mencuci telur agar perlekatannya hilang sehingga mudah ditebarkan. Selain larutan tersebut di atas dapat pula digunakan larutan tanah liat merah (lempung merah/tanah latosol). Caranya dengan melarutkan tanah merah 1 (satu) kg kedalam 2 (dua) liter air mendidih. Didihkan lagi agar steril, kemudian saring. Aerasikan dengan kuat sampai campuran merata. Penggunaannya adalah setiap 200 gram telur dapat dicuci dengan $100 \mathrm{~mL}$ air lempung. Sisa larutan lempung dapat disimpan di freezer dan digunakan sewaktu-waktu (Slembrouck et al., 2000).

Ikan yang mempunyai telur sedikit seperti platydoras maka perlakuan yang cepat dapat dikerjakan agar telur tidak melekat di tempat atau wadah pembuahan. Caranya adalah stripping betina dilakukan dalam wadah yang licin dan datar (piring atau cawan) yang benar-benar kering. Kemudian stripping induk jantan dilakukan langsung di atas telur, sperma akan langsung bercampur dengan telur. Piring diletakkan atau dipegang di atas tempat penetasan telur. Air dialirkan dengan kecepatan sedang sambil piring digoyang-goyang. Telur akan terbuahi dan jatuh ketempat penetasan dengan cepat bersamaan dengan aliran air dan akan melekat di tempat penetasan yang tidak akan dipindah-pindahkan lagi. Cara seperti ini hasilnya bagus, walaupun mungkin diperlukan keterampilan dan pengalaman.

\section{KESIMPULAN}

Kegagalan dalam pemijahan buatan dengan stimulasi atau rangsangan hormon sering dialami akibat kurang teliti atau akurat dalam setiap tahapan pemijahannya. Akurasi dan ketelitian yang tinggi dalam semua tahapan pemijahan maka kegagalan akan dapat diminimalisir, sehingga produksi larva/benih dapat sesuai dengan target yang diinginkan. Keterampilan dan pengalaman pembudidaya tentu sangat membantu keberhasilan dalam aplikasi teknologi ini.

\section{DAFTAR PUSTAKA}

Billard, R. 1982. On some pattern of reproduction physiology in male teleost fish. Proc. of the Intern Symp. on Reprod. Phys. of Fish. Wageningwn The Netherland. p. 192- 197.

Billard, R. 1989. Endocrinologi and fish culture. Fish Physiology and Biochemistry. Kupler Publ. Amsterdam. 7(14): 49- 56.

Billard, R. and M.P. Cosson. 1990. The energetic of fish sperm and motility. In. Control of sperm motility biological and clinical aspects (Editor by Cagnon). CRC Press. Boca Raton-Boston. p. 154- 170.

Donaldson, E.M. and G.A. Hunter. 1983. Induced final maturation, ovulation and spermiation in cultured fish I. Fish Physiology Academic Press. New York. Toronto. p. 351-390.

Satyani, D., T. Kadarini, dan O. Komarudin. 1999. Perkembangan gonad berbagai ukuran induk botia (Botia macracanthus Blkr.) pada pemeliharaan 0 jam/ hari J. Pen. Perik. Indonesia. 2(4): 37-42.

Slembrouck, J., J. Subagja, D. Day, and M. Legendre. 2000. Larval rearing In. Manual for Artificial Propagation of the Indonesian Catfish, Pangasius djambal. Edited by Slembrouck, J., O. Komarudin, Maskur, and M. Legendre. IRD dan Departemen Kelautan dan Perikanan Jakarta. p. 207-222.

Woynarovich, E. and L. Hovarth. 1987. The artificial propagation of warmwater finfishes. A manual for extention. Fisheries Technical Paper. No. 201. FAO. Rome. p. 69-80. 